\title{
Modelling renewable electricity generation for energy- autonomous dairy farms in New Zealand
}

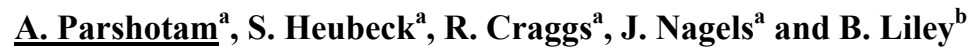 \\ aNational Institute of Water and Atmospheric Research (NIWA), Hamilton, New Zealand \\ ${ }^{b}$ National Institute of Water and Atmospheric Research (NIWA), Lauder, New Zealand \\ Email: a.parshotam@niwa.co.nz
}

Electricity provision is a significant and rapidly increasing cost on New Zealand dairy farms. Over and above rapid cost increases, newly established dairy farms (farm conversions) are faced with the very high capital costs for electricity network connection, often totalling several hundred thousand NZ\$. Progress with renewable energy technologies such as wind and solar-based electricity generation, and recent New Zealand advances with covered anaerobic pond biogas systems treating dairy shed effluent, offer options for establishing energy autonomous dairy farms which rely on a combination of renewable energy resources. Biogas can be stored over short to medium time periods and can therefore, in combination with other storage technologies, provide a back-up and buffer for intermittent renewable electricity generation from wind and solar energy.

In this paper, we analyse farm energy needs and renewable on-farm energy resource potential and present a model of a generic 600-cow dairy farm aiming for energy autonomy based on a combination of on-farm biogas, solar and wind technologies, as well as energy-storage technologies. The wind and solar potential was evaluated at four New Zealand locations with contrasting climatic conditions and representative of the majority of NZ dairy regions. For a Southland location, which indicated the best wind but poorest solar resource, energy balances were modelled at a finer scale. For this site the yields of a $30 \mathrm{~kW}$ wind turbine, a $30 \mathrm{~kW}$ solar set-up and the biogas resources available from the cow shed effluent of the 600-cow dairy farm were calculated. The energy yields were balanced against the farms projected energy demand and the buffer available from the biogas resource to determine the level of achievable energy autonomy.

Wind generation yields at farm scale were found to be very location specific and variable and even at the most favourable location in Southland, low compared to larger scale wind projects. The modelled $30 \mathrm{~kW}$ wind turbine could provide $30 \%$ of farm energy needs with weekly totals varying from $2-78 \%$. Solar generation was found to be more consistent and reliable at all 4 locations. On average, $38 \%$ of the Southland farm energy demand could be met with a $30 \mathrm{~kW}$ solar set-up, with weekly totals varying from 9$63 \%$. Biogas based electricity generation was able to supply $33 \%$ of the total energy demand of the model farm. In combination with the $32 \%$ of farm energy needs that could simultaneously be satisfied with biogas generator waste heat of 2/3 total farm energy needs could be met reliably and on demand with biogas.

Analysis of weekly farm energy demand indicated that nearly full energy autonomy could be achieved for most of the year with a combination of biogas and solar based generation in conjunction with some further established energy storage technology at the Southland farm. The combination of biogas and wind generation yielded poorer results.

For the combination of biogas and solar at Southland, the modelled energy shortfall (5.7\% of total) occurring over 20 weeks of the milking season could be met with a biogas generator back-up fuel such as LPG. For the Southland farm 1,587 kg LPG per year would be needed to achieve $100 \%$ energy autonomy with the described biogas and solar set-up. Increasing the solar generation capacity to meet the shortfall was found to be impractical as the PV set-up would have to have its capacity quadrupled to meet the shortfall occurring in the last week before the dry season starts. This initial modelling exercise showed that the concept of energy independent dairy farms based on primarily renewable energy resources is feasible in principal. More detailed work needs to be carried out to quantify the energy balances on a finer time scale (e.g. hourly) and required capacity of secondary energy storage equipment. Although outside the scope of this work it is indicated that the cost of the outlined alternative energy provision scheme will be favourable, provided it enables the farm to avoid the expense for a new electricity grid connection.

Keywords: Wind turbine, Solar, Biogas, Farm conversion, Flow chart, Spreadsheet model 
Parshotam, et al. Modelling renewable electricity generation for energy-autonomous dairy farms in New Zealand

\section{INTRODUCTION}

Dairy farming is New Zealand's biggest export earner (Statistics NZ, 2011) and projected to grow by 3\% p.a. in the foreseeable future (MAF, 2011). New Zealand's dominant position in international dairy export markets stems from a low cost, predominantly pasture-fed production system enabled by the relatively mild maritime climate. Historically, the near universal availability of core infrastructure in NZ, in particular roads and grid electricity supply, as well as the relatively low cost of electricity and fuels (MED, 2011), have been a further contributing factor in the success of the NZ dairy sector. These latter advantages are slowly eroding. For example in the last decade the unit cost of electricity for most dairy farms has increased between 50\% and 100\% (MED, 2011). Dairy farm conversions (from sheep and beef as well as arable farming and forestry), a core factor in the expansion of the NZ dairy sector in recent years, often require the building of cow sheds (milking platforms and adjacent support infrastructure) in locations where grid electricity is not easily available. Since the privatization of the NZ electricity sector in the 1990's the costs of new grid connections generally have to be borne entirely up-front by the owner of the conversion farm. Electricity grid connection costs ranging between NZ\$100,000 and NZ\$400,000 are not uncommon for remote dairy farm conversions (pers. com Mark Waldin (Landcorp Farming Ltd.), Colin Ferguson (Waikato Regional Council)). The problems of increasing grid electricity cost and the high cost of grid connections for dairy farm conversions, can both potentially be addressed through on-site electricity generation. Using renewable resources for on-site electricity generation can furthermore enhance the environmental credentials of New Zealand's export produce and address other issues such as national GHG emissions, fossil fuel depletion and national energy security.

Wind and solar resources are obvious choices for dairy farm electricity generation, since they are universally available to a certain degree and the technology is well understood and available. The key challenge with these resources, over and above cost implications, is to reconcile the variable and intermittent output of wind and solar generators with the fixed and rather spiky demand profile of NZ dairy farms. Biogas, another renewable energy resource potentially universally available at dairy farms could help to bridge variation in renewable electricity generation and on-farm demand. Low-cost and simple covered anaerobic pond technology has been shown to recover biogas from farm wastes in a reliable and cost effective manner (Craggs et al. 2008, Heubeck and Craggs 2010). Biogas can often supply over half of a typical NZ dairy farms energy needs, but total energy autonomy based on biogas utilization is only rarely achieved under NZ conditions. The major advantage of biogas as an energy resource over other renewables is that it can be stored for short to medium periods of time at little cost, and is available on-demand. This offers the possibility to use biogas as an "enabler technology" for the improved utilization of intermittent wind and solar generation. This paper presents a model to quantify and balance wind and solar generation with biogas utilization and other energy storage technologies in four NZ locations, and evaluates the most appropriate technology mix to attain $100 \%$ energy selfsufficiency.

\section{MODEL DEVELOPMENT}

In this paper we model renewable electricity generation for a typical 600-cow farm in four New Zealand locations, which could potentially use a combination of on-farm biogas, solar and wind technologies, as well as various energy storage technologies. The model was developed with the objective of testing the feasibility of attaining $100 \%$ energy autonomy for the dairy farm. Selected locations are in key dairy farming regions in New Zealand with contrasting climatic conditions. Detailed analysis of financial costs is not currently considered, since it is assumed that avoiding the cost of several hundred thousand NZ\$ on a network connection can compensate even a very large capital investment, if technologically feasible.

\subsection{Input data farm energy use and technology selection}

Energy Consumption on a Typical Dairy Farm

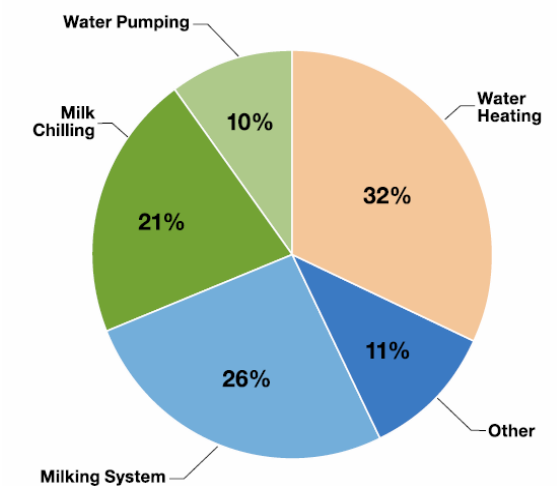

Figure 1: Break-down of typical NZ dairy farm electricity use (nonirrigation farms) Source: EECA (2009)

To guide technology selection and sizing of energy storage requirements for the model, it was assumed that the typical (off-grid) farm seeking 100\% energy autonomy would have an overall electricity consumption and electricity consumption profile equal to established on-grid dairy farms. For non-irrigated dairy farms an electricity consumption of $160 \mathrm{kWh} / \mathrm{cow} /$ year was determined by Wells (2001) and Sims et al. (2004). A typical electricity consumption profile for non-irrigated NZ dairy farms is shown in Figure 1 . The $36 \%$ electricity consumption for water pumps and the milking system occurs over two fixed time periods when 
Parshotam, et al. Modelling renewable electricity generation for energy-autonomous dairy farms in New Zealand

twice-daily milking ( $3 \mathrm{~h}$ each) occurs typically at 6:00-9:00 and 15:00-18:00; 7 days a week from August till May. The $11 \%$ other miscellaneous demand represents more or less a continuous base load from electricity users such as fence exciters, computers, lights, security systems, etc. In a typical modern New Zealand dairy shed, technologies such as efficient lighting and variable speed vacuum pumps, can help to reduce electricity consumption for these activities, but won't alter the timing of these energy uses. The $21 \%$ electricity demand for milk chilling (refrigeration) is also closely associated with the timing of the twicedaily milking periods. However, since cooling demand can be coupled with "cold storage technology" such as glycol storage or ice banks (Milfos, 2011) the energy demand for cooling can be spread over more of the day and in fact work as a buffer for intermittent renewable generation. Similarly, the $32 \%$ of electricity used for hot water heating can be spread over the day and used as a buffer for intermittent renewable electricity generation through the storage of hot water in insulated tanks. Moreover, in situations where biogas fuels on-farm electricity generation, generator waste heat can be used directly for water heating, thereby reducing electricity consumption.

\subsection{Extrapolation of fixed electricity consumption}

For the model farm, it is assumed that the number of days in a dairy season is 300 , the base case annual electricity consumption is $160 \mathrm{kWh} / \mathrm{cow} / \mathrm{y}$, herd size is 600 cows and the total annual electricity consumption is $96000 \mathrm{kWh} / \mathrm{y}$. It is also assumed that the twice-daily milking times are at 6:00-9:00 and 15:00-18:00 (7 days a week).

Table 1. Model farm electricity usage.

\begin{tabular}{lllllll}
\hline & $\begin{array}{l}\text { Milking } \\
\text { system }\end{array}$ & Water pumps & Miscellaneous & Milk chilling & Hot water & Total \\
\hline Percentage of total electricity usage & $26 \%$ & $10 \%$ & $11 \%$ & $21 \%$ & $32 \%$ & $100 \%$ \\
Daily usage (hours) & 6 & 8 & 24 & 12 & 12 & 102 \\
Daily total use $(\mathrm{kWh} / \mathrm{d})$ & 83 & 32 & 35 & 67 & 320 \\
Critical time usage $(\mathrm{kWh} / \mathrm{d})$ & 83 & 32 & 9 & & 124 \\
\hline
\end{tabular}

Based on the of typical (non-irrigation) NZ dairy farm electricity use (Figure 1) the daily electricity usage $(\mathrm{kWh} /$ day) was calculated for the milking system, water pumps, miscellaneous, milk chilling and hot water (Table 1). Approximated critical time electricity consumption (peak load during milking - fixed time activity) for each use is also presented. This gives a first indication for the sizing of generators and energy Table 2. Location of model farms and proximity to nearest climate station.

\begin{tabular}{llllll}
\hline Location & Lat. & Long. & $\begin{array}{l}\text { Nearest } \\
\text { climate } \\
\text { station ID }\end{array}$ & Name of station & $\begin{array}{l}\text { Distance } \\
\text { from site }\end{array}$ \\
\hline Waipu & -35.956 & 174.438 & 1287 & Whangarei Aero AWS & $21.8 \mathrm{~km}$ \\
Hamilton & -37.771 & 175.363 & 2112 & Hamilton AWS & $10.7 \mathrm{~km}$ \\
Oxford & -43.338 & 172.185 & 17609 & Darfield AWS & $17.7 \mathrm{~km}$ \\
Gore & -46.100 & 169.113 & 5778 & Gore AWS & $17.5 \mathrm{~km}$ \\
\hline
\end{tabular}

storage. These data are used in our calculations. For the non-milking (dry) season, it was assumed that the farm energy demand would be reduced to $300 \mathrm{kWh} /$ day.

\subsection{Model farms on-site energy resource}

The four chosen farm locations have different energy resource potential determined by wind profile and annual solar irradiance. The biogas resource is fixed by assuming an equal herd size of 600 cows and similar anaerobic digestion systems.

\section{Site information}

Model farm locations were chosen in the major dairying regions in New Zealand. The Northland location near Waipu as well as the Waikato location, near Hamilton are milder climate locations compared to

Table 3. Wind speed record period and average wind speed from the NIWA Climate database (NIWA 2011a).

\begin{tabular}{llll}
\hline Location & Name of station & $\begin{array}{l}\text { Period of wind speed } \\
\text { record }\end{array}$ & $\begin{array}{l}\text { Avg wind } \\
\text { speed }\end{array}$ \\
\hline Waipu, Northland & Whangarei Aero AWS & Jan 1994-Jun 2011 & 2.73 \\
Hamilton, Waikato & Hamilton AWS & June 1990-July 2011 & 2.9 \\
Oxford, Canterbury & Darfield AWS & Jan 1999-Feb 2011 & 3.42 \\
Gore, Southland & Gore AWS & Jan 1987-Jun 2011 & 3.36 \\
\hline
\end{tabular}

Table 4. Coefficients for the cubic regression equation fit to the power curves and cut-in speed $(\mathrm{m} / \mathrm{s})$ and cut-out speed $(\mathrm{m} / \mathrm{s})$ for the LF30 wind turbine.

\begin{tabular}{ccccccc}
\hline Turbine & A & B & C & D & Cut-in speed $(\mathrm{m} / \mathrm{s})$ & Cut-out speed $(\mathrm{m} / \mathrm{s})$ \\
\hline FL 30 & 0.001 & -0.169 & 5.354 & -16.705 & 3.5 & 60 \\
\hline
\end{tabular}


Parshotam, et al. Modelling renewable electricity generation for energy-autonomous dairy farms in New Zealand

the Canterbury location, near Oxford and Southland location near Gore. Table 2 gives farm coordinates and distance to the nearest climate station, used for climate data recording. Despite the higher latitude location of Southland site, the Canterbury site experienced more extreme summer to winter differences, and a generally more continental climate.

Wind resource The on-farm wind resource was projected based on average hourly wind records of the nearest weather stations over a greater than 10year recording period (NIWA 2011a). It is acknowledged that this choice of data source introduces an element of uncertainty to the model, since wind Table 5. Average cut-in speed and cut-out speed and proportion of time generating electricity for the LF30 wind turbine, at the four model farm sites.

profiles can vary even over short

\begin{tabular}{lll}
\hline Location & $\begin{array}{l}\text { Average speed after cut-in } \\
\text { and before cut out }(\mathrm{m} / \mathrm{s})\end{array}$ & $\begin{array}{l}\text { Proportion of time } \\
\text { generating }(\%)\end{array}$ \\
\hline Waipu & 5.4 & 41.0 \\
Hamilton & 5.4 & 34.9 \\
Oxford & 5.6 & 44.4 \\
Gore & 6.1 & 29.3 \\
\hline
\end{tabular}

distances. However since weather station and model farm locations are in the same geographic region (regarding altitude, distance to sea, wind shading mountains etc.) this selection of data source was deemed appropriate for a first estimate. In order to remain conservative with projections the wind speed figures where furthermore not corrected (upwards) for wind turbine height. For more refined future analysis more accurate wind profile projection tools, such as developed for the EnergyScape suite (NIWA, 2009) can be utilized. Table 3 gives the average wind speeds at the respective locations as well as the period of wind data recording. The wind turbine LF30 with a nominal power output of $30 \mathrm{~kW}$, manufactured by Fuhrlaender AG, was selected as model wind generator.

The power curve was obtained from Fuhrlaender AG (2010) product information, and forms the basis for our wind yield analysis at the four model farm sites. Values were read off the power curves and a cubic equation $\left(\mathrm{A} v^{3}+\mathrm{B} v^{2}+\mathrm{C} v+\mathrm{D}\right)$ was fit to these curves using a quasi-Newton method within SYSTAT v12, where $v$ is the wind speed. Estimates for the coefficients for this cubic equation, A, B, C and D are given in Table 4. The cut in and cut-out speeds, also given in Table 3, were estimated from the power curves. Table 5 gives the average speeds after cut-in and before cut-out $(\mathrm{m} / \mathrm{s})$ and the proportion of time the turbine would be generating electricity.

Solar resource A generic polycrystalline solar cell set-up, with $15 \%$ conversion efficiency and an area requirement of 7 $\mathrm{m}^{2} / \mathrm{kW}$ (peak), was assumed for solar electricity generation at the model farms. The cumulative solar energy was derived using solarview (NIWA 2011b) for estimating the amount of energy that is captured over a year by solar panels. The inputs are geographic position, compass direction and tilt of the PV panel. The supporting data is the topography of NZ and meteorological data from the past with data from measurement at sites per hour and interpolations between those sites. The model outputs cumulative gross solar energy in $\mathrm{kW}-\mathrm{hr} / \mathrm{m}^{2}$ as a plot. The hourly measured and inferred solar energy for the model farms was derived at 0,20 , and 75 degree tilt angles using the longest available radiation data in the national climate database (NIWA 2011a). The cumulative gross solar energy was converted to solar electricity on an hourly basis with a $\mathrm{MJ} / \mathrm{kWh}$ conversion factor of 3.6 and $15 \%$ conversion efficiency.

Biogas resource Covered anaerobic pond technology, as described in Heubeck and Craggs (2010) was selected as the technology of choice for biogas generation at the four model farm sites. Daily biogas heat and electricity availability was calculated based on manure availability in a dairy farm without a feed pad. The baseline waste production is estimated to be $0.3 \mathrm{kgVS} / \mathrm{cow} /$ day (VS = volatile solids). A biogas methane production factor of $0.2 \mathrm{~m}^{3} \mathrm{CH}_{4} / \mathrm{kgVS}$ was used for the calculations based on the dairy farm 
Parshotam, et al. Modelling renewable electricity generation for energy-autonomous dairy farms in New Zealand

monitoring results reported by Craggs et al. (2008). Biogas production in covered anaerobic ponds does vary seasonally, as a function of pond water temperature, pond thermal properties and dairy season profile. To approximate the annual average biogas methane availability to seasonal availability the following monthly factors were used: $133 \%$ for January; $133 \%$ for February; $110 \%$ for March; 100\% for April; 80\% for May; $25 \%$ for June; $25 \%$ for July; $66 \%$ for August; $80 \%$ for September; $90 \%$ for October; $110 \%$ for November and $120 \%$ for December. These figures are an approximation based on values reported by Craggs et al. (2008) and Heubeck and Craggs (2010) as well as operator experience with a covered anaerobic pond in the Taranaki region of New Zealand. Based on field experience it was also assumed that the anaerobic pond cover provided biogas storage equivalent to over one week of biogas production from the pond at peak summer output. On the model farms a spark ignition motor generator was used to convert biogas fuel into usable heat and electricity. A biogas generator electrical efficiency and biogas generator thermal efficiency of 30\% and $50 \%$ respectively was assumed. Projections of energy yields are based on the methane primary energy content of $9.38 \mathrm{kWh} / \mathrm{m}^{3} \mathrm{CH}_{4}$, (MED, 2011).

\subsection{Energy storage}

Three mechanisms were envisaged to intermediately store excess wind and solar electricity as well as biogas generator waste heat. Battery storage for powering miscellaneous demand 24/7, glycol cold storage and hot water storage for excess wind and solar electricity, as well as hot water storage for excess biogas generator waste heat. Adequate energy storage capacities for the hot water cylinder, glycol storage and batteries will be determined by future modelling.

\section{PRIORITISATION, FLOW CHART AND SPREADSHEET MODEL}

A flow chart (Figure 2) was developed for balancing the energy consumption requirements and supply requirements. These requirements are prioritized using, among others, the following set of rules: i) if the wind turbine and/or solar generator are running all instantaneous demands that may arise from miscellaneous demands, milking system, chillers and water pumps are satisfied first, ii) if there is a shortfall of electricity during milking time then the biogas generator will have to make up for the shortfall, iii) if there is an excess of wind and/or solar electricity over the instantaneous demand it goes into storage generally with the first priority being battery storage and the second priority being glycol storage and the third priority being hot water storage, and iv) if the
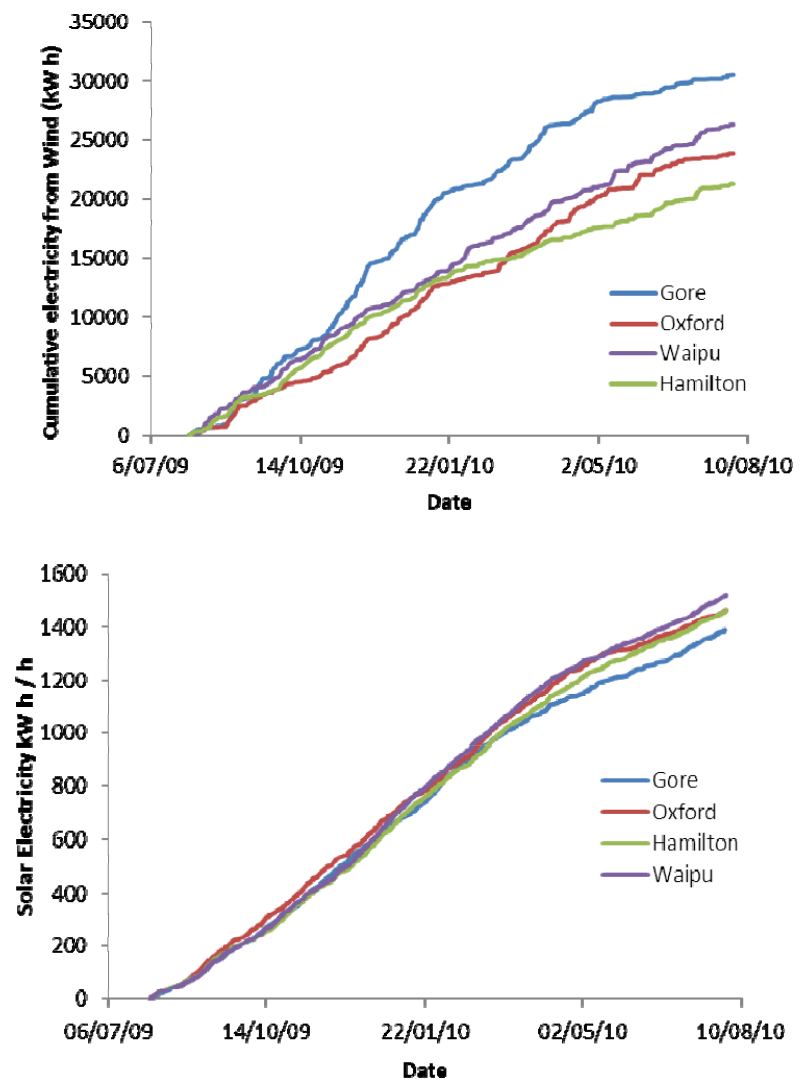

Figure 3. Cumulative plots of wind electricity and solar electricity generated.

battery and glycol storage is exhausted the biogas generator has to start up outside the milking time. A computer prototype spread sheet model was developed using Excel 2010 and coded in MS-VBA. The model is computed hourly from a given start and end time during the period of model runs. This spread sheet model was exemplarily applied to the generic 600 cow model farm located at Gore in Southland for the 2010 dairy season. This location was chosen, since Southland is one of the regions with the highest numbers of farm conversion in NZ.

\section{RESULTS}

Figure 3 shows cumulative daily electricity generation by wind and solar at the model farm sites during the arbitrarily chosen period, $1 / 8 / 2009$ to $31 / 7 / 2010$. Solar generation (based on $1 \mathrm{~m}^{2}$ of solar panel) does not 
Parshotam, et al. Modelling renewable electricity generation for energy-autonomous dairy farms in New Zealand

vary greatly between different model farm sites (using optimum tilt), and as indicated by the gentle slope changes of the cumulative curves, shows only a modest seasonal variation at all 4 sites. For the Gore site a total annual yield of $\sim 42,000 \mathrm{kWh} /$ year has been projected for a $30 \mathrm{~kW}$ set-up, however not all of the generated electricity may be utilized, e.g. at times when only insufficient energy storage capacity is available.

Wind generation shows $>25 \%$ variability between different sites, being highest at Gore and lowest at Hamilton in Waikato. The cumulative graphs indicate a (in comparison to solar), more erratic generation profile. At Gore $\sim 31,000 \mathrm{kWh} /$ year could be generated from a LF 30 turbine. Similar to solar generation, not all of the output may be utilized. Since covered anaerobic ponds provide biogas storage capacity (and hence buffer) of about a week, the total weekly generation from intermittent renewable resources is of interest to the operator of an energy autonomous farm.

For the Gore site, the total weekly wind and solar generation of a 30 $\mathrm{kW}$ wind and $30 \mathrm{~kW}$ solar generation set-up were calculated as a percentage of total weekly energy demand (Figure 4). In addition the percentage wind and solar generation during the critical demand period (morning and evening milking) to supply time specific

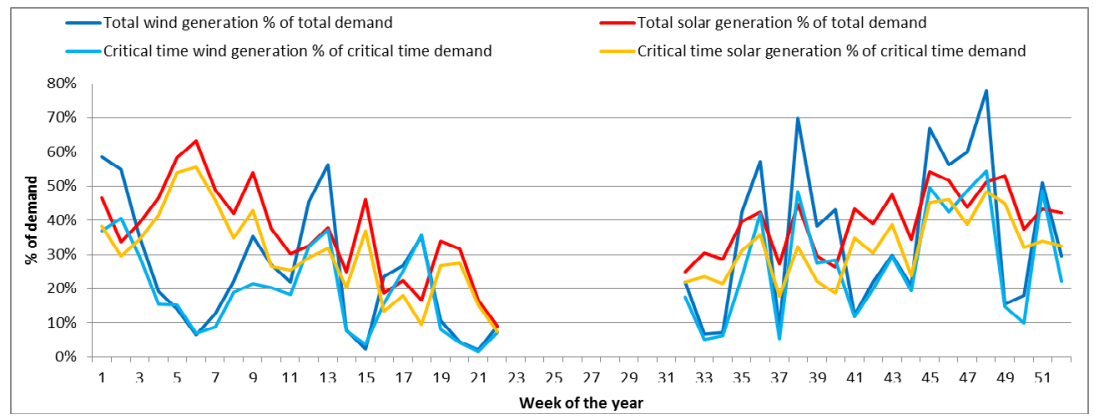

Figure 4. Wind and solar generation as a fraction of total, and time critical, weekly farm energy demand.

demands in the cow shed were also computed. The data gap between week 22 and 31 indicates the dry season, when there is no time critical demand in the cow shed. Wind generation can on average satisfy $30 \%$ of total demand (2-78\%) and $23 \%$ of time specific demand (2-55\%) weekly on-farm energy demand. Solar generation can on average satisfy $38 \%(9-63 \%)$ of total and $31 \%(7-56 \%)$ of time specific weekly on-farm energy demand. For the chosen location the capacity factor for solar generation $(16 \%)$ was higher than for wind generation (12\%). Both solar and wind generation show seasonal variation; however on a weekly basis the solar yields appear to be more consistent. At the model farm biogas CHP generation could satisfy $33 \%$ of total farm energy needs electrically and $32 \%$ thermally. The thermal supply (waste heat) is limited by the farms hot water needs which can always be met with generator waste heat throughout the year. For the Gore site weekly total generation from biogas (thermal and electrical), solar and wind have been added up and plotted together with inferred weekly energy demand for the 2010 dairy year (Figure 5). The graph indicates that biogas plus solar generation can satisfy farm energy demand most of the time. Addition of wind generation to the mix mainly adds to existing unused supply peaks, and doesn't help to balance energy shortfalls at the beginning and the end of the milking season.

\section{DISCUSSION}

Wind electricity yields varied between the sites. The projected utilization factors $(12 \%$ at the best site in Gore) compare rather poorly to utilization factors for utility scale wind projects in NZ $(>40 \%$, NZWEA, 2011) and poorer wind sites overseas e.g. Germany ( 20\%, BMU 2008). The erratic generation profile with large week to week differences necessitates large energy storage

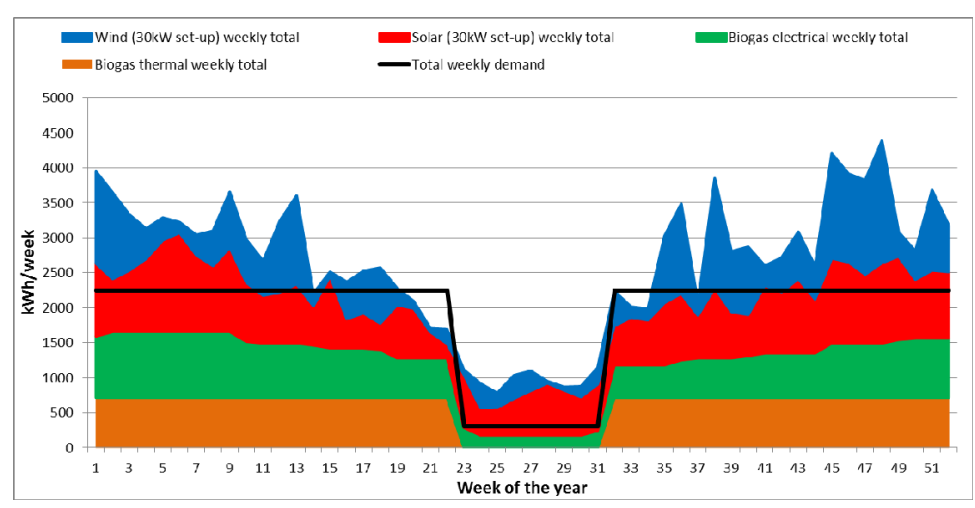

Figure 5. Weekly generated total from wind, solar and biogas at the Gore site. capacities, and powerful backup options. The amount of wind electricity generated during critical hours in a week however is well correlated (with $\mathrm{R}^{2}=0.95$ ) to the total wind electricity generated in a week, indicating no anti-cyclic wind generation in relation to critical demand. These figures indicate that despite being very case specific, 
Parshotam, et al. Modelling renewable electricity generation for energy-autonomous dairy farms in New Zealand

utilisation of wind generation in a dairy farming context even in better locations is problematic. Solar electricity yields varied less than wind yields between the four different sites and were also more consistent on a weekly basis. The capacity factor of $16 \%$ recorded for Gore compares well to utilization factors for solar PV generation recorded overseas e.g. Germany average 2007 ( 10\%, BMU 2008). The amount of solar electricity generated during critical demand times is well correlated (with $\mathrm{R}^{2}=0.95$ ) to the total solar electricity generated. The good correlation to the critical time demand is primarily due to the relatively good match between PV panel output and the critical demand of the afternoon milking period. The analysis indicates that compared to wind, solar would be the better matching intermittent renewable generation option for an energy autonomous dairy farm. Also, there appears to be little advantage in combining wind and solar generation at one location as wind generation appears to mainly aggravate weekly supply peaks rather than balance solar generation shortfalls. Biogas can supply the bulk of the on-farm energy needs from the manure feedstock base supplied by a cow shed without feed pad. The analysis has shown that a combination of biogas and solar technologies can achieve almost complete energy autonomy for a dairy farm. Several options exist to fill the remaining gaps $(5.7 \%$ of total) at the start and end of the milking season. These include using a back-up generator fuel (e.g. LPG, 1,587 kg/y required to meet shortfalls during weeks 17 to 23 , and 32 to 41). Another option would be the substitution of electric loads with thermal loads (e.g. compression chillers vs. absorption chillers), supplied from biogas generator waste heat currently underutilized or energy efficiency measures to reduce the overall farm energy consumption (e.g. variable speed vacuum pumps). Increasing the solar generation capacity to meet the shortfall was found to be impractical as the PV set-up would have to have its capacity quadrupled to meet the shortfall occurring in the last week before the dry season starts. The current modelling work has shown that the concept of an energy autonomous dairy farm based on the use of a combination of renewable resources is possible in principle. Further and more detailed modelling work needs to be carried out to determine minimum sizes for energy storage devices (battery, glycol storage, hot water storage) and rank and refine charging and decharging priorities. Future analysis must also consider losses associated with energy storage and provide indicative costs for field applications. As discussed, with the prospect of avoiding costly network connections and enabling the use of low or no cost fuels (wind, solar, biogas), off-grid dairy farms should be able to utilize technology that may be considered too expensive for many other sectors.

\section{REFERENCES}

BMU (2008). Renewable energy sources in figures - Status: June 2008, Federal Ministry for the Environment, Nature Conservation and Nuclear Safety (BMU), Berlin, Germany.

Craggs, R., Park, J. and Heubeck S. (2008). Methane emissions from anaerobic ponds on a piggery and a dairy farm in New Zealand. Australian Journal of Experimental Agriculture, 48, 142-146.

ECCA (2009). Dairy farmers milk free energy. June 2009. Published by Energy Efficiency and Conservation Authority. http://www.eeca.govt.nz/sites/all/files/dairy-farmers-milk-free-energy-june09.pdf

Furhlaender AG (2010). Product information wind turbine LF 30.

Heubeck, S. and Craggs, R. (2010). Biogas recovery from a temperate climate covered anaerobic pond. Water Science.\&Technology. 61 (4), 1019-1026.

MAF (2011). Situation and Outlook for New Zealand Agriculture and forestry (SONZAF), June 2011. Published by Ministry of Agriculture and Forestry.

MED (2011). New Zealand Energy Data File 2011, Energy Information and Modelling Group, Ministry of Economic Development, Wellington, New Zealand.

Milfos (2011). Milfos product information. http://www.milfos.com/catalogue/2011/06 Cooling.pdf.

NIWA (2009). EnergyScape Basis Review - Section 2 Renewable Resources. Analysis report prepared for FRST, June 2009.

NIWA (2011a). National Institute of Water and Atmospheric Research (NIWA). The National Climate Database. http://cliflo.niwa.co.nz/.

NIWA (2011b). National Institute of Water and Atmospheric Research (NIWA) Solarview online tool; http://solarview.niwa.co.nz/

NZWEA (2011). Case study: Tararua wind farm. Published by New Zealand Wind Energy Association. http://www.windenergy.org.nz/nz-wind-farms/operating-wind-farms/tararua.

Sims et al. (2004). Energy Use in the New Zealand Agricultural Industry with emphasis on the dairy sector. Report prepared for ECCA. Massey University, Palmerston North.

Statistics NZ (2011). Overseas Merchandise Trade: June 2011, Worksheet table 5, Press release, $26^{\text {th }}$ of July 2011, Statistics New Zealand Tatauranga Aotearoa, Wellington, New Zealand.

Wells, C. M. (2001). Total Energy Indicators of Agricultural Sustainability : Dairy Farming Case Study Final Report. Report to MAF Policy. Dept. of Physics, University of Otago. 